\title{
Design of Zakat Accounting Guidelines Based on Comparative Analysis of PSAK 109 and FAS (9) AAOIFI
}

\author{
M. Sudirman, Muhammad Hasbi Zaenal, Sigid Eko Pramono \\ Tazkia Islamic Economics College (IAIT)
}

Paper to be presented at International Conference of Zakat 2019

3-4 October, Universitas Padjadjaran, Bandung, Indonesia

\begin{abstract}
This research will examine Sharia Accounting specifically which deals with the analysis of Zakat based on comparative analysis of PSAK 109 with FAS (9) AAOIFI and makes a draft of Zakat Accounting Guidelines based on comparison of PSAK 109 with FAS (9) AAOIFI which can be applied in Indonesia. The research used in this research is a descriptive qualitative research that is a method that describes, describes, compares a data and a situation and explains a situation in such a way that a conclusion can be drawn, with in-depth interviews, discussions and literature studies in order to obtain information from primary and secondary sources, using content analysis, literature review and SWOT.
\end{abstract}

Keywords: Zakat, Accounting of Zakat, SAK Zakat, FA Zakat of AAOIFI, Zakat Accounting Guidelines

\section{INTRODUCTION}

Understanding of Zakat, Infaq, Sadaqah (ZIS) has been sharia regulated and explained in the Qur'an. Understanding of Zakat is regulated among others in the letter: AlBaqoroh verse 43, At-Taubah verses 60, 103 and 104, An-Nisa verse 77 and understanding of infaq / Sadaqah is regulated among others in the letter: Surat Al-Baqarah verse 254, Al -Hadid verse 7, Adz-Dzaariyat verse 19 and Surat Al-Ma'aarij verses 24-25.

Surah Al-Baqarah (2) Verse (43), which means: "And establish prayer, pay alms and bow with those who bow". According to (Katsir 2015), the Word of God to the People of the Book "and establish prayer", meaning: "Allah ordered them to pray together with the Prophet Muhammad Sallallahu Alaihi Wassalam and His Word" pay alms ", meaning God ordered them to pay zakat and give it to the Prophet Muhammad
Sallallahu Alaihi Wassalam. His Word "and bow with those who bow", meaning to order them to bow with those who bow from the people of Prophet Muhammad Sallallahu Alaihi Wassalam. (Kathir, 2015, p.233).

Muhammad (2005: 159) zakat is an obligation of every Muslim who meets the Nisab (the minimum limit of assets that must be issued zakat), in order to purify the soul, individual and society. Zakat is a pillar of Islam that has the most visible social side compared to other pillars. Zakat is another person's right attached to an individual.

Ascarya, Beik, Zaenal (2018), Zakat is an instrument of Islamic pillars with a broad range of dimensions, ranging from aspects of faith, economics, and social; a big problem dimension for a nation as big as Indonesia. So, it is very unfortunate when the dynamics of Indonesian adultery are not recorded properly and precisely, or only 
discussed with the basis of the word "roughly".

Zakat, State Gazette of the Republic of Indonesia Year 2011 Number 115, Supplement to the State Gazette of the Republic Indonesia Number 5255, hereinafter referred to as "UUPZ" and then followed up with the enactment of Government Regulation Number 14 of 2014 concerning the Implementation of Law Number 23 of 2011 concerning Management of Zakat (Indonesian Republic of Indonesia State Gazette Year $2 \mathrm{O} 4$ Number 38, Supplement to the State Gazette of the Republic of Indonesia Number 5508), hereinafter referred to as ("PP UUPZ"). To carry out its duties and functions, the BAZNAS is assisted by the Zakat Collecting Unit (UPZ) is an organizational unit formed by BAZNAS to assist in the collection of zakat (Article 1 number 9 UUPZ). Triyani, Beik \& Baga (2018), Zakat management institutions have a very strategic role to implement sharia provisions related to the obligation to pay zakat and distribute zakat to those entitled to receive it

In order to optimize the collection and utilization of zakat to realize public welfare and poverty reduction, on April 232014 the President of the Republic of Indonesia Number 3 of 2014 was issued concerning Optimization of Zakat Collection in Ministries / Institutions, Secretariat General of State Institutions, Secretariat General State Commission, Regional Government, StateOwned Enterprises and Regional-Owned Enterprises through the National Amil Zakat Agency, hereinafter referred to ("Inpres $3 / 2014$ ") and then followed by the issuance and enactment of the National Amil Zakat Board Regulation Number 01 of 2014 concerning Guidelines for Governance How to Submit Considerations for Appointment / Dismissal of the Chairperson of the Provincial National Amil Zakat Board hereinafter referred to as ("Perbaznas 01/2004") and Regency / City Amil Zakat Board and Regulation of the National Amil Zakat Agency Number 02 Year 2014 Regarding Guidelines for Procedures for Granting Recommendations for Establishing Le mbaga Amil Zakat hereinafter referred to ("Perbaznas 02/2004"). Beik (2009), Zakat instruments have tremendous potential. For this reason, it is necessary to have a strong commitment and cooperation among all stakeholders of zakat, both the government, Parliament, agencies and institutions of amil zakat, as well as the community as a whole in realizing sustainable zakat development.

Zaenal (2016) explains the Zakat as referred to in the quote below:

"Zakat is the third pillar of Islam after the confession of faith and prayer. It considers as the important obligation from the Muslim around the world in order to empathize with others and to develop the economy of ummah".

To assist BAZNAS in implementing the collection, distribution and utilization of zakat, the community can form LAZ after obtaining permission from the Ministry of Religion officials. In the framework of implementing the granting of LAZ formation permits it is necessary to prepare guidelines for granting LAZ formation permits, thus as stipulated in the Decree of the Minister of Religion of the Republic of Indonesia Number 333 of 2015 concerning Guidelines for Granting Amil Zakat Institution Permit Formation hereinafter referred to as ("KMA 333/2015"). Mukhlisin (2016), The duty of amil zakat is to remind the Muslim community to carry out the third pillar of Islam after prayer and prayer that is paying zakat, one of which rests on the call of QS AtTaubah (9): 103, which means: Take alms from their property, in order to cleanse and purify them, and pray for them. 
The UUPZ also emphasizes the importance of transparency and accountability as important factors needed by the community to grow their trust in the Zakat Management Organization (OPZ). Mukhlisin \& Hudaib (2014) explains their accountability related as quoted:

"As the IIFIs are established to demonstrate their accountability for both shareholders and society, therefore, not only their operation must uphold the mutuality concept but also their reporting mechanism"

ZIS accounting standards applicable in Indonesia, namely PSAK No. 109 regarding ZIS accounting has been issued by the Indonesian Institute of Accountants (IAI) and endorsed in 2010. This PSAK applies to amil, which is an organization/entity managing zakat whose formation and confirmation are regulated based on laws and regulations intended to collect and distribute zakat and infaq. / alms, not for sharia entities that receive and distribute ZIS but not their main activities, with PSAK 109 it is expected that uniformity and comparability of financial statements will be made and so that OPZ is also ready to be audited by public accountants and as a guideline zakat accounting and then the Zakat Forum (FOZ), has published the Amil Zakat Accounting Guidelines (PAAZ), guidelines for the implementation of the preparation of financial statements based on PSAK 109, but the guidelines are not a rule or regulation issued by IAI. The importance of accounting, especially for transparency and financial accountability, is already explained in AlQuran Surat Al-Baqarah verse 282.

Antonio \& Mukhlisin (2013) explains transparency in disclosure as quoted:

"In conclusion, one main role of Islamic financial institutions is responsible for ensuring that the IFIs code of conducts in business must be in accordance with the principles of the Shari'ah (S). Therefore, all their activities should be made transparent in disclosing all activities and therefore specific financial reporting is required. This is parallel with the message from AlQur'an 2:282.

Internationally, zakat accounting is regulated by AAOIFI (Accounting and Auditing Organizations for Islamic Financial Institutions) based in Bahrain. In AAOIFI FAS (Financial Accounting Standard) No. 9 which became effective as of January 1, 1991, covers various aspects of zakat, including tax rates. Tax rates will be distinguished between companies that use the lunar calendar and the solar calendar. FAS 9 also explained 2 (two) methods of measuring zakat, namely the net assets and net invested funds methods.

Mukhlisin \& Antonio (2018) stated the power of accounting and auditing as quoted:

"Accounting and auditing standard for Islamic financial institution have strengthened the existence as released internationally by Accounting and Auditing Organisation for Islamic Financial Institutions (AAOIFI)".

According to Pramono (2015), stated that one of the main objectives of the AAOIFI organization is to design and disseminate accounting and auditing standards that can be applied internationally by all Islamic institutions. AAOIFI also plays an important role in pursuing harmonization of shariabased regulations in all jurisdictions of Islamic countries and Pramono (2018) states: "Some countries that follow the AAOIFI (Accounting and Auditing Organization for Islamic Financial Institutions) frameworks have already adopted". 
Previous research conducted by Kristin \& Umi (2011), Puspitasari \& Habiburrochman (2013), Rahman (2015), Shahnaz (2015), Pratama \& Roziq (2017), Rizal, Fitri \& Minazzulami (2017), Habib (2016), it was found that PSAK 109 cannot be fully implemented and not all zakat management organizations apply the entire contents of this PSAK. At present some of OPZ in making financial statements still do not apply PSAK 109 or have not fully implemented PSAK 109 or do not comply with PSAK 109, some OPZ still use simple financial reporting so that the reporting forms and formats for each OPZ are different. The causal factor has not been implemented in PSAK 109 due to OPZ's human resource constraints. So to overcome these problems training and assistance is needed for OPZ related to the application of PSAK 109. PSAK 109 contains five financial statements according to PSAK No. 109 of them are balance sheets, reports on sources and uses of funds, reports on changes in assets under management, cash flow statements and notes on financial statements and the implementation of Zakat Infaq / Alms accounting have not yet been implemented and implemented.

Amelia \& Qibtiyah (2015), there are several differences in the accounting treatment of zakat in BAMUIS BNI based on PSAK 45 and PSAK 109, which are as follows: PSAK 109 is an accounting standard that is made for Zakat and Infaq / Alms accounting, so that it has been prepared with due regard to sharia Islam. PSAK 109 has regulated the existence of Non-Current Assets under Management, namely fixed assets obtained from Zakat and Infaq / Alms funds in the form of facilities and / or infrastructure that are physically in the management of Amil Zakat for more than one year such as schools, hospitals, or ambulances. In accordance with the needs of sharia, PSAK 109 emphasizes that the operational burden of the Amil Zakat Institution must be taken from the portion of amil.

Adnan \& Abu Bakar (2009), gave a critique of AAOIFI FAS (9) by comparing it to MASB (Malaysian Accounting Standard Board), which is an accounting organization in Malaysia, has tested the understanding of zakat and the concept of zakat, discussed the definition and classification, recognition, measurement, presentation and disclosure. The only two conceptual discourse referred to in western or conventional accounting and one is Islam, as explained by AAOIFI, the definition and recognition of zakat in turn is related to presentation.

Sareal (2013), explains the accounting treatment of zakat focusing on the measurement and disclosure of zakah AAOIFI No.9. This research can be considered as additional evidence to determine the concept of zakat that is better than the concept of zakat and will make an agreement with the requirements for recognition, measurement and disclosure of financial statements and be a useful tool to meet the various needs of Islamic Finance. The findings show that AAOIFI No.9 accounting can contribute more to obtaining financial reporting transparency, in other words, financial statements will be more transparent and easy and there are recommendations in order to improve the quality of transparency of financial reporting and for examples of key differences between domestic accounting standards and AAIOFI.

The issue of the adoption of PSAK 109 in OPZ has come to the attention of IAI. This can be seen where one of the agenda of DSAS-IAI activities related to the preparation of Sharia SAK in the 2019 period is to conduct a "Post implementation review" targeted at "Quarter 4/2019". 
(http://iaiglobal.or.id/v03/files/file_sak/DSA S_Terkini.pdf).

\section{LITERATURE REVIEW}

Zakat In terms of language is the basic word of zaka which means blessing, growth, cleanliness, and good. But the strong maraji 'according to Wahadi and others, the basic word of zakat, means to grow and grow, to make a lot, to make more meaningful, and to protect that wealth from destruction. Thus, Nawawi quotes from Wahidi's opinion (Qardhawi, 2007: 34).

According to Ali in Sulchantifa (2006: 11), zakat has similarities with infaq or alms. Namely worship or deeds related to property. However, there is a difference between zakat with donation and alms.

Mukhlisin (2016), The duty of amil zakat is to remind the Muslim community to carry out the third pillar of Islam after prayer and prayer that is paying zakat, one of which rests on the call of QS At-Taubah (9): 103, which means: Take alms from their property , in order to cleanse and purify them, and pray for them.

According to https://baznas.go.id/profil, the National Amil Zakat Agency (BAZNAS) is the official and only body established by the government based on Presidential Decree No. 8 of 2001 which has the duties and functions of collecting and distributing zakat, infaq, and alms (ZIS) at the national level. The issuance of Law Number 23 of 2011 concerning Management of Zakat further strengthens the role of BAZNAS as an institution authorized to conduct zakat management nationally. In the Act, BAZNAS is declared as a nonstructural government institution that is independent and is responsible to the President through the Minister of Religion, thus, BAZNAS together with the Government is responsible for overseeing the management of zakat that is based on: Islamic Sharia, trustworthiness, expediency, justice, legal certainty, integrated and accountability.

Kustawan et. Al (2012), argues that the purpose of establishing the guidelines of zakat accounting are to assist users in understanding the accounting treatment and preparation of financial statements in accordance with PSAK 109 concerning Zakat and Infaq/Alms Accounting so it can increase the comparability of financial statements among zakat institutions.

Hafidhuddin (2012), in terms of the accounting cycle, the preparation of financial statements is the final stage of the process of making accounting reports. A report begins with the emergence of a transaction, followed by the process of preparing financial statements, including interpreting the financial statements, the financial statements show or report what management has done (stewardship) or management accountability for the resources entrusted to him.

Mursyidi (2006), Accounting (accountancy) comes from the word to account, one of which means "to count". Technically, accounting is defined as the process of recording, classifying, summarizing financial transactions measured in units of money, and reporting the results.

Accounting can be defined as the process of recording, classifying, summarizing, reporting, and analyzing an organization's financial data (Jusup, 2005: 5). According to Mulyadi (1993: 2) accounting is "the process of processing financial data to produce financial information that is used to enable decision making based on information in decision making".

The main thing related to accounting is the recording of financial transactions, recognition, valuation, and disclosures in financial statements. Islamic accounting is a social science prophetic, all the rules relating to Islamic accounting are normatively obtained from the commands in the Qur'an that are used as a direction for accounting 
practices. The direction of accounting practices will certainly be in accordance with sharia. In Islamic accounting, the recording of accounting transactions is associated with the spirit of Islam, according to Al Baqarah 282 (Fajarwati and Sambodo, 2010).

Husein As-Syahatah (2004), Zakat accounting is a frame of thought and activity that includes the basics of accounting and operational processes related to the determination, calculation and valuation of assets and income that must be tackled, determine the level of zakat and the distribution of the results to the post - the post is in accordance with the law and the basic principles of Islamic law. In other words the accounting of zakat is competent in the calculation of zakat and its distribution to its posts in accordance with the law and the principles of Islamic law.

According to http://www.jurnal.id (2019), the Statement of Financial Accounting Standards-International Financial Report Standard (PSAK) is another name for SAK (Financial Accounting Standards) which was applied by the Indonesian Accounting Association (IAI) in 2012. This standard is used for entities or businesses that have public accountability, namely entities that are registered or are still in the process of registering on the capital market such as public companies, insurance, banking, state-owned companies or pension fund companies). PSAK is the same as SAK, both aims to provide relevant information for users of financial statements. While the use of IFRS itself is determined because Indonesia is a member of IFAC (Internatinal Federation of Accountants) which makes IFRS as their accounting standard.

According to

http://iaiglobal.or.id/v03/beritakivitas/detailberita-1152-has-terbit-dsasterkini-edisi-perdana (2019), IAI is a professional organization that houses all accountants in Indonesia. IAI was founded on December 23, 1957 based on the spirit of nationalism of Indonesian Accountants in the early days of Indonesian independence. IAI is a member and founder of the International Federation of Accountants (IFAC) and the ASEAN Federation of Accountants (AFA). At present IAI is also a member of Chartered Accountants Worldwide (CAW), a professional organization that houses professional accountants with Chartered Accountant (CA) designations worldwide.

The Latest DSAS is a publication media prepared by the IAI Technical Team which contains a summary of the results of the discussion in the DSAS-IAI meeting within a certain period of time. The Latest DSAS will be published periodically to inform the latest developments of the Sharia SAK development process carried out by DSAS-IAI.

According to http://www.jurnal.id, Financial Accounting Standards (GAAP) are standard methods and formats in presenting information on financial statements of a business activity. In Indonesia, accounting standards have developed into 4 pillars that have been prepared by following the development of the business world.

Indonesian Institute of Accountants (2019), Sharia Accounting Standards (SAS) is a Statement of Financial Accounting Standards (PSAK) Sharia intended for entities that conduct sharia transactions both sharia institutional entities and non-sharia institutions. SAS development is carried out by following the general but Sharia-based SAK model with reference to the MUI fatwa.

DSN MUI Institute (2019), SAK Syariah has unique characteristics that are not fully in accordance with the concepts used in general SAK. The process of preparing Sharia SAK always refers to the fatwa issued by the National Sharia Council of the Indonesian Ulema Council (DSN MUI). 
The Syariah Accounting Standards Board was formed in Jakarta at the 8th Congress of IAI in 1998. The Syariah Accounting Standards Board (DSAK) is under the auspices of the Indonesian Institute of Accountants (IAI).

KDPPLK was first approved by the Indonesian Institute of Accountants Financial Accounting Standards Board (DSAK IAI), June 27, 2007. Letter from the IAI National Management Board (DPN) No. 0823-B / DPN / IAI / XI / 2013, all sharia accounting products previously issued by DSAK IAI are transferred to the IAI Sharia Accounting Standards Board (DSAS).

The Indonesian Ulema Council (MUI) held a National Sharia Council Formation Team (DSN) meeting on October 14, 1997. The MUI Leadership Council issued Decree No. Kep-754 / MUI / II / 1999 dated February 10, 1999 concerning the Establishment of the MUI National Sharia Board. The MUI Leadership Council held a ta'aruf event with the Management of DSNMUI on February 15, 1999 at Hotel Indonesia, Jakarta.

The compilation of Sharia Economic Law (KHES) which is coordinated by the Indonesian Supreme Court recently is a response to new developments in the study and practice of muamalat law (Islamic economics) in Indonesia.

According to the IAI Sharia SAK (2019), PSAK 109: Zakat and Infaq / Alms Accounting is issued by the Indonesian IAI Sharia Accounting Standards Board on April 6, 2010. The National Sharia Board of the Indonesian Ulema Council provides a statement of sharia compliance with PSAK 109 through letter Number: U -290 / DSN MUI / VIII / 2011 concerning Sharia Conformity Statement PSAK 109: Accounting for Zakat and Infaq / Sadaqah dated August 16, 2011.

Table of Contents of PSAK 109 is 43 paragraphs, consisting of:
- Introduction includes Purpose, Scope, Definition, Characteristics

- Recognition and Measurement includes Zakat (Acceptance of Zakat, Distribution of Zakat), Infaq / Alms (Receiving infaq / alms, Distribution of infaq / alms)

- Presentation

- Disclosures include Zakat, Alms / Alms

- Transitional Provisions

- Effective date

According to AAOIFI Accounting (Auditing and Governance Standards) (2015), FAS (9) regarding Zakah, the table of contents of FAS (9) is as follows

- Zakah

- Preface

- Statement of the Standard:

1. Scope of Standard

2. Accounting Treatments of Zakah Base

2.1. Determination of Zakah base

2.1.1. Net assets method

2.1.2. Net invested funds method

2.2. Treatment of Zakah in the financial statements

2.2.1. Case in which the Islamic bank is obliged to pay Zakah

2.2.2. Case in which the Islamic bank is not obliged to pay Zakah

2.2.3. The Zakah due from the Islamic bank as well as amounts of Zakah received from other sources of funds shall be presented in the statement of source of and uses of funds in the Zakah and charity fund.

3. Disclosure Requirements

3.1. Disclosure shall be made in the notes accompanying the 
financial statements of the method and for determining the Zakah base and the items included in this base.

3.2. Disclosure shall be made in the notes accompanying the financial statements of the ruling of the Shari'a supervisory board of the Islamic bank on the issues related to Zakat that are not included in this standard.

3.3. Disclosure shall be made in the notes accompanying the financial statements of whether or not the Islamic bank as a holding company pays its share of Zakat obligations in its subsidiaries.

3.4. In case the Islamic bank does not pay Zakat, disclosure shall be made in the notes accompanying the financial statements of the Islamic bank of the amount of Zakat that is due from each share.

3.5. Disclosure shall be made in the notes accompanying the financial statements of the amount of Zakat that is due from the equity of investment accountholders.

3.6. Disclosure shall be made in the notes accompanying the financial statements of whether or not the Islamic bank collects and pays Zakat on behalf of holders of investment accounts and other accounts.

3.7. Disclosure shall be made in the notes accompanying the financial statements of the restrictions imposed by the Shari'a supervisory board of the Islamic bank in determining the Zakat base. An example of such a restriction is: in the net invested funds method, the total of net fixed assets and investments not acquired for trading should not exceed the total of paid up capital and reserves.

3.8. Disclosure requirements in Financial Accounting Standard No. (1): General Presentation and Disclosure in the Financial Statements of Islamic Banks and Financial Institutions shall be observed.

\section{Effective Date}

This Standard shall be effective for financial statements for fiscal periods beginning muharram 1420 A.H. or 1 January 1999 A.D.

- Adoption of the Standard

Appendix (a); Example of Items Included in Determining the Zakah Base

Appendix (b): Example Illustrating How to Determine the Zakah Base Appendix (c): Brief History of the Preparation of the Standard Appendix (d): Justoce Rules for Zakah Appendix (e): Reasons for the Standard

Appendix (f): Basis for Conclusion Appendix (g): Conclusion

Primary sources (Al-Qur'an and AsSunnah), which are Surat Al-Baqarah verse 43, Al-Baqarah verse 254, An-Nisa verse 77, At-Taubah verse 60, At-Taubah verse 103104, Al-Hadid verse 7, Adz-Dzaariyat verse 19, Surat Al-Ma'aarij verse 24-25. and hadith:

"Islam is built on five pillars; syahadat there is no god but Allah and Muhammad are His messengers, upholding prayers, paying zakat, fasting Ramadan, and performing Hajj for those who are 
able "(Reported by Bukhari and Muslim).

"Verily, Allah obliges Zakat on the rich people of Muslims on their property with a limit according to the adequacy of fuqara among them. Poor people will not lack when they are hungry or not dressed except because of the actions of the rich among them. Remember that God will reckon them hard and poignantly pounce on them." (HR Thabrani).

This research will initially begin by conducting an In-depth Interview to get an overview of Zakat Accountants by using Content Analysis, Normative and Empirical then proceed with making Zakat Accounting Guidelines using SWOT analysis. The results of the in-depth interview will be used as a chart to make the Zakat Accounting Guidelines, so that the Zakat Accounting Guidelines can be used by BAZNAS and IAI or parties related to Zakat Accounting in the form of Managerial Implications.

\section{RESEARCH METHODOLOGY}

The research used in this research is a descriptive qualitative research that is a method whose nature is to describe, describe, compare data and conditions and explain a situation in such a way that a conclusion can be drawn.

According to Ian Dey (1993), Qualitative Data Analysis is: "The core of qualitative analysis lies in these related processes of describing phenomena, classifying it, and seeing how our concepts interconnect".

The qualitative method in this research was carried out by the process of indepth interviews, discussions and literature studies in order to obtain information from primary and secondary sources, using content analysis, literature review and SWOT.

The population in this study is a person or group of people who understand and are experienced in Zakat Accounting in Indonesia, while the sample used in this study is 7 (seven) experts who understand Islamic Accounting which is very adequate and received recognition from the public as well as practitioners in fields related to the educational background of the Bachelor of Accounting, Masters and Doctor who have expertise and expertise in the field of Islamic Accounting. The sampling method used was purposive sampling so that the study obtained the desired results.

Data collection techniques such as: documentation, observation (observation) and interviews. Data analysis techniques using descriptive methods, which describe the reality on the ground and compare with theories from existing references and draw conclusions.

Anwar and Ismal (2011) describes the data that has been processed as quoted: "Are explain that there are three reasons why data that has been processed aims to convert the data into new data that are (1) to measure the size of the data reflecting the importance of the output, (2) to facilitate random initialization of weights before training the network, (3) to make all normal data to avoid different measurements because of different input units".

SWOT is an abbreviation to describe Strengths, Weaknesses, Opportunities and Threats which are strategic factors for a particular company.

\section{CONCLUSION}


1. Comparing the accounting of ZAK PSAK 109 in Indonesia with FAS (9) AAOIFI internationally

2. Draft Zakat Accounting Guidelines for PSAK 109 in Indonesia with FAS (9) AAOIFI internationally.

\section{RECOMMENDATIONS}

a. Theoretically.

- This research is useful for the knowledge from the review of Draft Zakat accounting guidelines for PSAK 109 in Indonesia with FAS (9) AAOIFI internationally.

- Academics

- Students

b. Practically

- Government

- Ministry of Religion

- BAZNAS

- FOZ

- Accountant

- Practitioner

- Community

- Parties related to Zakat.

- ZAK Accounting Guidelines based on PSAK 109 and FAS (9) AAOIFI can contribute to BAZNAS and IAI

\section{REFERENCES}

Al-Qur'an (2013). Qur'an and translation. Ministry of Religion of the Republic of Indonesia. Jakarta.

Bassam, Sheikh Abdullah Abdurrahman Alu (2010). Syarah Hadith Muslim Bukhari Law. Bogor: Ramsa Putra.

Mubarakfuri al, Shaykh Shafiyyurrahman (2014). Sahih Tafsir Ibn Kathir. Ratification of the Hadith Based on the Books of Shaykh Muhammad Nashiruddin al-Albanidan Ulama
Other Hadith Experts accompanied by a Detailed and Easy to Understand Discussion. Bogor: Library Team Ibn Kathir.

Amiruddin and Zainal Asikin (2014) Introduction to Legal Research Methods. Jakarta: Rajawali Press.

Ascarya (2013). Solution to Prevent Financial Crisis in Islamic Economic Perspective: ANP Approach Proceeding of the International Symposium on the Analytic Hierarchy Process. , without years, Analytic Network Process: A New Approach to Qualitative Research in Basic Concepts. Central Bank Research \& Education Center, Bank Indonesia. \& Masrifah. A.R (2014). The Analytic Network Process application uses SuperDecision 2.2.6.

, Beik, I.S., \& Rahmawati, S (2016), Designing Risk Management for Zakat Management, Proceeding, Department of Islamic Economics \& Finance.

, Beik I.S, Zaenal, et al (2018). Risk Management Management of Zakat. Center for Strategic Studies - National Amil Zakat Agency, Department of Islamic Economics and Finance - Bank Indonesia, ISBN: 978-602-5708-05-3

Manan, Bagir (1999). Journal of Law. Legal Research. Bandung: Center for Research and Development Unpad. Prime.

As-Syahatah, Husein (2004). Zakat Accounting: A Practical Guide to Calculating Contemporary Zakat. Jakarta: Progressive Library.

Hafidhuddin, Didin (2012) Zakat Management in Indonesia. Jakarta: Zakat Forum (FOZ)

Indriantoro, Nur \& Bambang Supomo (2012). Business Research 
Methodology for Accounting and Management. Yogyakarta: BPFE.

Jusup, Haryono Al (2005). Accounting Basics. Sixth Edition. Yogyakarta: STIE YKPN

Kustiawan, Teten et al (2012). Amil Zakat Accounting Guidelines (PAAZ). Guideline for the Implementation of PSAK-Based Financial Statements 109. Jakarta: Zakat Forum (FOZ)

Mulyadi (1993). Management Accounting: Concepts, Benefits and Engineering. Second Edition. Yogyakarta: STIE YKPN , Beik I.S, Zaenal, et al (2018). Risk Management Management of Zakat. Center for Strategic Studies - National Amil Zakat Agency, Department of Islamic Economics and Finance - Bank Indonesia, ISBN: 978-602-5708-05-3

Manan, Bagir (1999). Journal of Law. Legal Research. Bandung: Center for Research and Development Unpad. Prime.

As-Syahatah, Husein (2004). Zakat Accounting: A Practical Guide to Calculating Contemporary Zakat. Jakarta: Progressive Library.

Hafidhuddin, Didin (2012) Zakat Management in Indonesia. Jakarta: Zakat Forum (FOZ)

Indriantoro, Nur \& Bambang Supomo (2012). Business Research Methodology for Accounting and Management. Yogyakarta: BPFE.

Jusup, Haryono Al (2005). Accounting Basics. Sixth Edition. Yogyakarta: STIE YKPN

Kustiawan, Teten et al (2012). Amil Zakat Accounting Guidelines (PAAZ). Guideline for the Implementation of PSAK-Based Financial Statements 109. Jakarta: Zakat Forum (FOZ)

Mulyadi (1993). Management Accounting: Concepts, Benefits and Engineering.
Second Edition. Yogyakarta: STIE YKPN

Mursyidi (2006). Zakat and Contemporary Accounting. Bandung: PT Remaja Rosdakarya.

Suprapto, Paulus Hadi (2008). Normative Legal Research Methods, Approaches, Legal Materials, Legal Materials Collection Techniques and Analysis of Legal Materials. Paper, Seminar on Legal Research Methods Communication Forum for Postgraduate Students of Law Faculty of Law, Universitas Brawijaya.

Soekanto, Soerjono and Sri Mamudji (2004). Normative Legal Research: A Short Review. Jakarta: Rajawali Press.

Wasilah, Sri Nurhayati (2015). Islamic Accounting in Indonesia, Issue 4, Jakarta: Four Salemba.

Sugiyono (2009). Statistics for Research. Bandung: Alfabeta.

Tanjung, H \& Devi, A (2013). Islamic Economic Research Methodology. Bekasi: Gramata Publishing.

The 1945 Constitution of the Republic of Indonesia.

Law Number 12 of 2011 concerning Formation of Regulations and Regulations. Republic of Indonesia State Gazette Year 2011 Number 82, Additional Republic of Indonesia State Gazette Number 5234

Law Number 23 of 2011 concerning Management of Zakat, State Gazette of the Republic of Indonesia of 2011 Number 115, Supplement to the State Gazette of the Republic of Indonesia Number 5255.

Republic of Indonesia Government Regulation Number 14 of 2014 concerning Implementation of Law Number 23 of 2011 concerning Management of Zakat, State Gazette of the Republic of Indonesia of 2014 Number 38, Supplement to State 
Gazette of the Republic of Indonesia Number 5508.

Presidential Instruction of the Republic of Indonesia Number 3 of 2014 concerning Optimization of Zakat Collection in Ministries / Institutions, General Secretariat of State Institutions, Secretariat General of State Commissions, Regional Governments, State Owned Enterprises, and Regional Owned Enterprises through National Amil Zakat Agencies.

Zakat Charity Regulations Number 01 of 2014 concerning Guidelines for Procedures for Submission of Appointment / Dismissal of Leaders of Provincial National Amil Zakat Board and Regency / City National Amil Zakat Board.

Zakat Charity Regulations Number 02 Year 2014 concerning Guidelines for Procedures for Granting Recommendations to Establish Amil Zakat Institutions.

Republic of Indonesia Supreme Court Regulation Number: 02 of 2008 concerning Compilation of Sharia Economic Law (KHES).

Decree of the Minister of Religion of the Republic of Indonesia Number 333 of 2015 concerning Guidelines for Granting Amil Zakat Institution Permit Formation.

Compilation of Islamic Law (KHI)

Compilation of Sharia Economic Law

/ KHES) or The Compilation of

Islamic Economic

Fatwa of the National Sharia Council of the Indonesian Ulema Council (DSN-MUI Fatwa).

AAOIFI (Accounting, Auditing and Governance Standards for Islamic Financial Institutions, Accounting and
Auditing Organizations for Islamic Financial Institutions), Bahrain.

FAS 9 AAOIFI

International Financial Reporting Standards (IFRS)

Guidelines for Islamic Financial Accounting Standards (PSAK) 109.

Indonesian Institute of Accountants. 2009. Exposure Draft Statement on Financial Accounting Standards No. 1 (Revised 2009) - Presentation of Financial Statements. Jakarta.

Indonesian Institute of Accountants. 2011. Statement of Financial Accounting Standards No. 109 Financial Reporting on Zakat Accounting, infaq / alms. Jakarta.

Abdullah, Abdul Azis (2014). Factors Influencing a Business Towards Zakat Payment In Malaysia. Sultan Zainal Abidin University. Malaysia. International journal of Science Commerce and Humanities. Journal Volume 2 No. 3 of 2014. http://erep.unisza.edu.my/2399/, accessed on 5 November 2015. Page 147.

Sareal, Adel Mohammed (2013). Accounting Treatment of Zakah: Additional Evidence from AAOIFI, Director of MBA, College of Graduate Studies and Research, Ahlia University, Kingdom of Bahrain, Journal of Islamic Banking and Finance, Vol. 1 No. 1, December 2013

Habib, Anang Ariful (2016). The Principle Of Zakat, Infaq, And Sadaqah Accounting Based SFAS 109, Jember University Postgraduate Program, Journal of Accounting and Business Education, 1 (1), September 2016.

Anwar, S \& Ismal, R (2011). Robustness analysis of artificial neural networks and vector machine support in making prediction. In Parallel and Distributed 
Processing with Applications (ISPA), 2011 IEEE 9th International Symposium on (pp. 256-261). IEEE.

Kristin, P Ari and Umi Khoirul Umah (2011). Application of Zakat Accounting in Amil Zakat Institutions, (Studies in LAZ DPU DT Semarang Branch), IAIN Walisongo Semarang, VALUE ADDED, Vol.7, No.2, March 2011 August 2011, http://jurnal.unimus.ac.id \%.

Ascarya (2014). Sustainable Conventional and Islamic Microfinance Models for Microenterprises, ISRA International Journal of Islamic Finance, Vol.6 Issue 2.

Amelia, Erika and Maria Qibtiyah (2015). Zakat Accounting Treatment Based on PSAK 45 and PSAK 109 in BNI Bamuis of the Faculty of Economics and Business UIN Syarif Hidayatullah Jakarta, The Journal of Tauhidinomics Vol. 1 No. 2 (2015): 183-198

Beik, Irfan Syauqi (2009). Analysis of the Role of Zakat in Reducing Poverty: Case Study of Dompet Dhuafa Republika, Zakat \& Empowering, Journal of Thought and Ideas - Vol II 2009

Adnan, Muhammad Akhyar (2009). Accounting treatment for corporate zakat: a critical review, Department of Accounting, Faculty of Economics and Management Sciences, International Islamic University Malaysia, Kuala Lumpur, Malaysia, and Nur Barizah Abu Bakar Department of Accounting, Faculty of Economics and Management Sciences, International Islamic University Malaysia, Kuala Lumpur, Malaysia, International Journal of Islamic and Middle Eastern Finance and Management Vol. 2 No. 1, 2009 pp. 32-45 q Emerald Group Publishing Limited 1753-8394 DOI 10.1108/17538390910946258.
Mukhlisin, Murniati \& Muhammad Syafii Antonio (2018). Meta-analysis on Direction of Accounting Standards for Islamic Financial Institutions: Case Studies in United Kingdom and Indonesia, Al-Iqtishad: Jurnal Ilmu Ekonomi Syariah (Journal of Islamic Economics), Volume 10 (1), January 2018, P-ISSN: 2087-135X; E-ISSN: 2407-8654, Page 231 - 254

Adnan, Muhammad Akhyar (2009). Accounting treatment for corporate zakat: a critical review, Department of Accounting, Faculty of Economics and Management Sciences, International Islamic University Malaysia, Kuala Lumpur, Malaysia, and Nur Barizah Abu Bakar Department of Accounting, Faculty of Economics and Management Sciences, International Islamic University Malaysia, Kuala Lumpur, Malaysia, International Journal of Islamic and Middle Eastern Finance and Management Vol. 2 No. 1, 2009 pp. 32-45 q Emerald Group Publishing Limited 1753-8394 DOI 10.1108 / 17538390910946258.

Mukhlisin, Murniati \& Muhammad Syafii Antonio (2018). Meta-analysis on Direction of Accounting Standards for Islamic Financial Institutions: Case Studies in the United Kingdom and Indonesia, Al-Iqtishad: Journal of Islamic Economics (Journal of Islamic Economics), Volume 10 (1), January 2018, P-ISSN: 2087 -135X; E-ISSN: 2407-8654, Page 231 - 254

Pramono, Rossieta \& Soedarmono. Income smoothing behavior and the procyclical effect of loan loss provisions in Islamic banks Global evidence. Department of Islamic Economics and Finance, Bank Indonesia, Jakarta, Indonesia and College of Islamic Economics, Tazkia University, Bogor, Indonesia, Faculty 
of Economics and Business, University of Indonesia, Depok, Indonesia, and Faculty of Business, Sampoerna University, Jakarta, Indonesia. Journal of Islamic Accounting and. Business Research. Vol. 10 No. 1, 2019. pp. 2134. (C) Emerald Publishing Limited. 1759-0817. DOI 10.1108/JIABR-092014-0032

Rizal, Sri Adella Fitri and Hadiyati Minazzulami (2017). PSAK 109: Review of Its Application in the Solok Regency Baznas PSAK 109: A Study of Its Application At the Baznas Solok Regency, Faculty of Economics and Islamic Business IAIN Batusangkar, Jl. Sudirman No. 137, Kuburajo, Five Tribes, Batusangkar Imara Journal, Volume 1, Number 1, December 2017.

Pratama, Rozy Widhi Bayu and Ahmad Roziq (2017). Implementation of Zakat Infaq and Sadaqah Accounting Based on PSAK 109 Implementation of Zakat, Infaq and Sadaqah Accounting Based on PSAK 109, Accounting Department, Faculty of Economics and Business, University of Jember (UNEJ), Jln. Kalimantan 37, Jember 68121, e-Journal of Business Economics and Accounting, 2017, Volume IV (1): 35-39

Shahnaz, Sabrina (2015). Application of PSAK No.109 Regarding Financial Reporting of Zakat, Infaq / Alms Accounting at the Amil Zakat Board of North Sulawesi Province Sam Ratulangi Manado, EMBA Journal, Vol. 3, December 4, 2015, Pg. 315-324. Rahman, Taufikur (2015). Zakat, Infaq and Alms Accounting (PSAK 109): Efforts to Increase Transparency and Accountability of Zakat Management Organizations (OPZ), Salatiga State Islamic Religion Institute (IAIN),
Muqtasid Journal, Volume 6, Number 1, June 2015.

Astuti, Tri Budi, Saiful Anwar and Junarti (2019). Development of Sharia Tourism Object in Gorontalo Bubohu Village: SWOT and ANP Approach. Economic Forum, 21 (1) 2019, 1-11, ISSN Print: 1411-1713 ISSN Online: 2528-150X

Puspitasari, Yulifa and Habiburrochman (2017). Application of PSAK No.109 on Obligatory and Voluntary Disclosure of Airlangga University, Jl. Airlangga 4-6, Surabaya, Journal of Multiparadigm Accounting, JAMAL Volume 4 Number 3, Pages 330-507, Malang, December 2013. ISSN 20867603, e-ISSN 2089-5879.

Mukhlisin, Murniati (2014). Exploring reflexivity and resistance of Indonesian Islamic financial institutions towards IASB and AAOIFI financial reporting standardization projects. $\mathrm{PhD}$ thesis, University of Glasgow.

Pramono, Sigid Eko (2015). Income Smoothing Behavior and Procyclical Effects in Islamic Banks; Cross Country Studies. Dissertation. Economics and Business Faculty. University of Indonesia

Antonio, Syafii \& Murniati Mukhlisin (2013). Analysis on Determinants in Implementation of Accounting Standards for Islamic Financial Institutions; Narrative Study between United Kingdom and Indonesia, Seventh Asia Pacific Interdisciplinary Research in Accounting Conference, Kobe 26-28 July, 2013

\& Mohammad Hudaib (2014). Is there a political economy of accounting in financial reporting standardization for the Islamic financial institutions? Conference Paper · July 2014 
Antonio, Syafii \& Murniati Mukhlisin (2013). Analysis on Determinants in Implementation of Accounting Standards for Islamic Financial Institutions; Narrative Study between United Kingdom and Indonesia, Seventh Asia Pacific Interdisciplinary Research in Accounting Conference, Kobe 26-28 July, 2013

\& Mohammad Hudaib (2014). Is there a political economy of accounting in financial reporting standardization for the Islamic financial institutions? Conference Paper · July 2014

Beik Irfan Syauqi \& Laily Dwi Arsyianti. (2013). Optimization of Zakat Instrument in Indonesia's Poverty Alleviation Program, Conference Paper, May 2013

Zaenal, Muhammad Hasbi, Muhammad Choirin, Khonsa Tsabita, Amelya Dwi Astuti, Ayu Solihah Sadariyah. (2016). Puskas Working Paper Series, Principles of Amil Zakat and Best Practice Recommendation, Center of Strategic Studies of the National Board of Zakat (BAZNAS).

Triyani, Nina, Irfan Syauqi Beik, Lukman M Baga (2018). Manajemen Risiko pada Badan Amil Zakat Nasional (BAZNAS), Risk Management at Badan Amil Zakat Nasional (BAZNAS), Article-April 2018

Moeljono, Anton. Indonesia Dictionary

Munawwir, A.W. (1997). Al-Munawir's Complete

Arabic-Indonesian

Dictionary Surabaya: Progressive Literature. and Muhammad Fairuz (2007). The Complete Indonesian-Arabic AlMunawir Dictionary. Surabaya: Progressive Library.

Ministry of National Education (2012). Big Indonesian Dictionary Language Center, Gramedia Main Library. Jakarta.
Echols, John M. and Hasan Syadily (2003). An-English-Indonesian Dictionary, Jakarta: PT. Gramedia Main Library.

Editorial Team of the Big Indonesian Dictionary (2011). Indonesia Dictionary. Jakarta: Balai Pustaka Language Center of the Ministry of National Education (2008). Indonesian dictionary. Jakarta: Language Center of the Ministry of National Education.

https://dsnmuiinstitute.com/standardaccountance-finance-syariah/,DSNMUI Institute, Promoting Sharia Economics and Recognizing Community Economics, downloaded on February 22, 2019.

http://iaiglobal.or.id/v03/standardaccountance-finance/sas-efektif-16-sak syariah-effective-per-1-january-2018, downloaded on March 28, 2019.

https://forumzakat.org/, downloaded on March 28, 2019.

https://forumzakat.org/about-foz/, downloaded on March 28, 2019.

https://dsnmuiinstitute.com/standardaccountance-finance-syariah/,DSNMUI Institute, Promoting Sharia Economics and Recognizing Community Economics, downloaded on February 22, 2019.

http://iaiglobal.or.id/v03/standardaccountance-finance/sas-efektif-16-sak syariah-effective-per-1-january-2018, downloaded on March 28, 2019.

https://saepudinonline.wordpress.com/pusta $\mathrm{ka} /$ kompilation/kompilation-hukumekonomi syariah /, downloaded April 25, 2019.

https://blog.asrifahmi.com/2015/12/peng understanding-ifrs-internationalfinancial-accounting-standard.html, downloaded April 23, 2019

https://akuntansikeuangan.com/organization al-accountance-syariah-internasionalaaoifi/ downloaded April 23, 2019. 
http://kbbi.web.id/klausul, Big Indonesian Dictionary (KBBI)

https://dsnmuiinstitute.com/standardaccountance-finance-syariah/, downloaded June 16, 2019, at 07.00 WIB

http://iaiglobal.or.id/v03/tentang_iai/dewanpengurus-nasional, downloaded on June 16, 2019, at 08.40 WIB

http://www.iaiglobal.or.id/v03/beritakivitas/detailberita-

1126=kepemership-baru-iai- period20182022, downloaded on June 16, 2019 , at 08.45 WIB

https://www.jurnal.id/id/blog/2017-4-

standar-akuntansi-keuangan-yang-

berlaku-di-indonesia/, downloaded on June 16, 2019, at 09.10 WIB

https://dsnmui.or.id/kami/sekilas/, downloaded on June 16, 2019, at 09.30 WIB.

https://baznas.go.id/profil, downloaded on June 16, 2019, at 12:30 WIB.

https://forumzakat.org/about-foz/, downloaded ON June 16, 2019, at 13.00 WIB.

http://iaiglobal.or.id/v03/files/file_sak/DSA

S_Terkini.pdf, downloaded on July 1, 2019, at 20.00 WIB.

Murniati Mukhlisin, Where Are Our Zakat?, 2016, Friday 12 Feb 2016 21:59 WIB https://republika.co.id/berita/o2fwbv3 36/kemanakah-zakat-kita, downloaded on July 15, 2019.
M. Sudirman

Tazkia Islamic Economics College (IAIT)

m.sudirman321@gmail.com

Muhammad Hasbi Zaenal

Tazkia Islamic Economics College (IAIT)

Sigid Eko Pramono

Tazkia Islamic Economics College (IAIT) 